\title{
The relationship between epilepsy and sexual dysfunction: a review of the literature
}

Muhammad Atif ${ }^{1}$, Muhammad Rehan Sarwar ${ }^{1 *}$ and Shane Scahill ${ }^{2}$

\begin{abstract}
Background and objectives: Regardless of the disease states that people suffer from, maintaining sexual function is an important indicator of quality of life. The objective of this review was to figure out the relationship between epilepsy, antiepileptic drugs (AEDs) and sexual dysfunction.

Results: In various epidemiological and clinical studies, epilepsy has been correlated with a reduction in sexual function. This sexual dysfunction is not always detected in epileptic patients until systematic efforts are put in place, as part of the assessment and treatment process. Therefore, precise evaluations of the incidence of treatment related sexual dysfunction in epileptic patients is still lacking.

Conclusions: This literature review concluded that sexual function is influenced by the pathophysiology of epilepsy, as well as through the use of AEDs. To maximize quality of care in patients with epilepsy and those patients with other disease states who receive AEDs, it is important to address the status of the patient's sexual function as part of the initial routine assessment and with any treatment related follow-up. Minimizing the effects of AED related sexual dysfunction can be achieved by raising awareness among patients, providing education and training for physicians regarding sexual dysfunction and obtaining a baseline sexual history from the patient so are important recommendations. In addition, systematic studies are needed to explore the risk and mechanism of such treatment related side effects on sexual function.
\end{abstract}

Keywords: Epilepsy, Sexual dysfunction, Antiepileptic drugs, Epidemiology, Relationship

\section{Background}

Historically discussion around sexual practices and associated dysfunction was taboo. However, in the modern era, awareness of issues associated with sexual dysfunction has been more commonly aired. Western civilization has become more open-minded about discussing sexual dysfunction, and in particular about erectile dysfunction (ED) in men, often associated with chronic disease. With this opening up of society there has been encouragement for people to think about their sexual performance and to seek advice from health consultants (Laumann et al. 1999; Kaufman et al. 2015).

\footnotetext{
*Correspondence: rehansarwaralvi@gmail.com

1 Department of Pharmacy, The Islamia University of Bahawalpur, Bahawalpur, Punjab, Pakistan

Full list of author information is available at the end of the article
}

The very first orally available drug for male ED was sildenafil (Viagra) which not only treated the problem but also through marketing campaigns, increased awareness among people. These days ED is considered amongst the general public to be a "medical condition" that can be managed. In terms of etiology both physical (ED in men due to circulatory disorders) and psychological factors (inadequate interpersonal associations, psychiatric illness) are responsible for sexual dysfunction. Another cause of sexual dysfunction is the use of drugs such as anti-hypertensive (Fogari et al. 1998), anti-psychotics (Baldwin and Birtwistle 1997), anti-depressants (Baldwin et al. 1997; Goldstein and Goodnick 1998) and antiepileptic drugs (AEDs) (Hamed et al. 2015; Kirmani et al. 2014; Lombardi et al. 2015; Meryn 2015; Svalheim et al. 2015; Urso et al. 2014; Kaufman et al. 2015; Sivaraaman 
and Mintzer 2011; Kaufman and Struck 2011b). The link between sexual dysfunction and drug induced as opposed to disease induced effects is complicated, and the case of epilepsy and AEDs has received less attention than one might expect. Sexual dysfunction may impact on compliance and is reported to be dose dependent with various AEDs (Kaufman and Struck 2011a). For example, case reports of gabapentin-induced sexual dysfunction suggest that the minimum total daily dose required for sexual dysfunction is $900 \mathrm{mg}$ (Dalal and Zhou 2008; GRANT and $\mathrm{OH} 2002)$.

\section{The human sexual response and sexual dysfunction}

Natural sexual response of a human can be divided into four stages and disturbance can occur in any one these stages;

1. Desire typically this consists of fantasies about, and the desire to have, sexual activity.

2. Excitement the individual sense of sexual enjoyment, associated with physiological alterations, including penile tumescence and erection in men, and pelvic vasocongestion, inflamed external genitalia, and lubrication and extension of the vaginal canal in women.

3. Orgasm height of sexual enjoyment, by the discharge of sexual tension and rhythmic contraction of perineal muscles as well as reproductive organs.

4. Resolution sense of comfort and muscular leisure. Physiologically men are noncompliant to erection and orgasm for a varied time period, while women might be capable to respond to additional stimulation.

The label 'sexual dysfunction' has been classified in the International Classification of Mental and Behavioral Disorders, 10th edition (ICD-10) (World Health Organization 1992) (for those people who were incapable of enjoying their sexual relationship as they want). The ICD-10 sexual dysfunction categorization is not based on organic pathophysiology or infection. Both ICD-10 and Diagnostic and Statistical Manual of Mental Disorders, fourth edition (DSM-IV) (American Psychiatric Association 2000) utilized the same classificatory proposal (Table 1).

Men and women can both suffer from sexual dysfunction the difference being women tend to express a lack of sexual enjoyment and/or interest, whilst men face sexual dysfunction related largely to physical response including failure to achieve an erection and/or premature ejaculation (McCabe et al. 2016). There has been dialogue to suggest that the categorical approaches to sexual

\section{Table 1 Standard classification system for sexual dysfunc- tion \\ F52.0 Lack or loss of sexual desire \\ F52.1 Sexual aversion and lack of sexual enjoyment \\ F52.2 Failure of genital response \\ F52.3 Orgasmic dysfunction \\ F52.4 Premature ejaculation \\ F52.5 Non-organic vaginismus \\ F52.6 Non-organic dyspareunia \\ F52.7 Excessive sexual drive \\ F52.8 Other sexual dysfunction, not caused by organic disorder or disease \\ F52.9 Unspecified sexual dysfunction, not caused by organic disorder or disease}

dysfunction as defined by the ICD-10 and DMS-IV highlight the obscure, diverse and exclusive approaches whereby any person or couple could share their sexual problems (Bancroft 2009). It is evident if any phase of sexual response is changed, other phases may also be affected. Therefore, for diagnosis and subsequent treatment to be successful with sexual dysfunction it is essential to intervene with any relevant presenting complaint, rather than merely focusing on the standard diagnostic criteria.

\section{Epidemiology of sexual dysfunction}

The epidemiology of sexual dysfunction has not been broadly discussed in the literature; or at least the literature has not been reviewed and synthesized. Thirty years ago prevalence data for sexual dysfunction were derived according to the DSM-III by Nathan et al., who analyzed twenty two studies about sexual dysfunction in the general population. Methodological issues in this analysis indicated that an extensive estimation might be made (Nathan 1986). The incidence of reduction of sexual desire was found to be $35 \%$ in women, $16 \%$ in men, premature ejaculation 35\% and ED $10-20 \%$ in men and in female, orgasmic complication was found to be $5-15 \%$. According to a study conducted in the United States (US), sexual dysfunction was more common in women (43\%) than men (31\%) (Laumann et al. 1999). In the case of women, low sexual desire (22\% prevalence), arousal difficulty (14\%) and sexual pain (7\%) have been observed. Whilst for men premature ejaculation (21\%), low sexual desire (5\%) and ED (5\%) have been observed. Sexual dysfunction rates can be different depending upon the population being studied and the nature of sexual dysfunction being evaluated. The data represented here demonstrates a high prevalence of sexual dysfunction for both males and females (Christensen et al. 2011; Ernst et al. 1993; Lindau et al. 2007; Hendrickx et al. 2016). Table 2 
Table 2 Studies of sexual dysfunction in the general population

\begin{tabular}{|c|c|c|c|}
\hline Population & Subjects (M/F) & Dysfunctions assessed (\%) & References \\
\hline 40-year-old Danish women & $0 / 324$ & $\begin{array}{l}\text { Impaired interest (41.8), orgasmic difficulties (36.7), dissatisfac- } \\
\text { tion (35.4), pain/dyspareunia (1.3) }\end{array}$ & Garde and Lunde (1980) \\
\hline 35-59-years-old Oxford women & $0 / 521$ & $\begin{array}{l}\text { Impaired interest (17), orgasmic difficulties (16), pain/dys- } \\
\text { pareunia (8) }\end{array}$ & Osborn et al. (1988) \\
\hline \multirow[t]{2}{*}{ 29-year-old men, 30-year-old women } & \multirow[t]{2}{*}{$197 / 218$} & $\begin{array}{l}\text { Men dissatisfaction (21), impaired interest (7), premature } \\
\text { ejaculation (4) }\end{array}$ & \multirow[t]{2}{*}{ Ernst et al. (1993) } \\
\hline & & $\begin{array}{l}\text { Women dissatisfaction (21), impaired interest (16), orgasmic } \\
\text { difficulties (7), pain/dyspareunia (6) }\end{array}$ & \\
\hline Iranian women aged 20-60-years-old & $0 / 2626$ & $\begin{array}{l}\text { Orgasmic difficulties (37), low sexual desire (35), lubrication } \\
\text { disorders (33.7), dissatisfaction (31.5), arousal disorders (30), } \\
\text { pain/dyspareunia (26.7) }\end{array}$ & Safarinejad (2006) \\
\hline \multirow[t]{2}{*}{ US adults (57-85-years of age) } & \multirow[t]{2}{*}{$1455 / 1550$} & $\begin{array}{l}\text { Men erectile difficulties (37), lack of interest in sex (28), climax- } \\
\text { ing too quickly (28), anxiety about performance (27), inability } \\
\text { to climax (20) }\end{array}$ & \multirow[t]{2}{*}{ Lindau et al. (2007) } \\
\hline & & $\begin{array}{l}\text { Women lack of interest in sex (43), lubrication disorders (39), } \\
\text { inability to climax (34), finding sex not pleasurable (23), pain } \\
\text { (17) }\end{array}$ & \\
\hline British women aged 18-85-years-old. & $0 / 1489$ & $\begin{array}{l}\text { Low sexual desire (17.3), dissatisfaction (14.6), orgasmic dif- } \\
\text { ficulties (13.5), arousal disorders (13.3), lubrication disorders } \\
\text { (11.5), pain/dyspareunia (11.5) }\end{array}$ & Burri and Spector (2011) \\
\hline \multirow[t]{2}{*}{ Danes aged 16-95-years-old } & \multirow[t]{2}{*}{$2120 / 2295$} & $\begin{array}{l}\text { Men premature ejaculation (7), erectile dysfunction (5), anor- } \\
\text { gasmia (2), dyspareunia (0.1) }\end{array}$ & \multirow[t]{2}{*}{ Christensen et al. (2011) } \\
\hline & & $\begin{array}{l}\text { Women lubrication insufficiency (7), anorgasmia (6), dyspareu- } \\
\text { nia (3), vaginismus (0.4) }\end{array}$ & \\
\hline Swiss men aged 18-25-years-old & $3886 / 0$ & Erectile dysfunction (29.9), premature ejaculation (11.4) & Mialon et al. (2012) \\
\hline \multirow[t]{2}{*}{ Flemish men and women 14-80-years-old } & \multirow[t]{2}{*}{$651 / 695$} & $\begin{array}{l}\text { Men erectile dysfunction (7.1), premature ejaculation (6.3), } \\
\text { hyperactive sexual desire (3.3) }\end{array}$ & \multirow[t]{2}{*}{ Hendrickx et al. (2016) } \\
\hline & & $\begin{array}{l}\text { Women lubrication dysfunction (9.6), absent or delayed } \\
\text { orgasm (7.4), low responsive sexual desire (6.9), low sponta- } \\
\text { neous desire (5.3) }\end{array}$ & \\
\hline
\end{tabular}

summarizes the key findings of studies published on sexual dysfunction among the general population.

The major categories of sexual dysfunction are influenced by various aspects. First, the means of enquiry and type of data reporting mechanism i.e. the occurrence of sexual dysfunction in one prospective study was $14 \%$ when relying on spontaneous self-reporting, but 58\% when the doctor directly asked the patient about it (Montejo-Gonzalez et al. 1997). Second, the attitudes of people with respect to disclosing and fully discussing their sexual dysfunction issues with their physician is strongly influenced by the culture of a society (Bhavsar and Bhugra 2013).

To provide an example, this is especially the case with Muslim people whereby discussing anything sexuallyrelated, including issues like sexual dysfunction outside of marriage is prohibited. This can make it very difficult for Muslim clients to seek help from health professionals; however, there mechanisms in place where it may be allowed for treatment purposes (Sungur and Bez 2016). Any sexual activity outside of marriage is also banned under Islam, but the religion encourages the enjoyment of sex and sensitivity to the needs of the spouse within heterosexual marriages. Therefore, it is critical for health professionals to be aware of the role of culture in defining sexual dysfunction and how cultural factors can be considered when initiating treatment as well as in therapeutic engagement and alliance between patient and practitioner.

Third, sexual dysfunction can be defined in many terms and is reliant on the belief of what is usual or normal in a sexual relationship (Bhugra and de Silva 2007). Finally, temporal trends can occur with spikes in concern about disorders, as increased awareness of sexual matters and availability of medical treatments increase the numbers who perceive themselves as suffering from sexual dysfunction and come forward to seek treatment (Baldwin 2001).

\section{Sexual dysfunction in epileptic patients}

Epilepsy is a significant chronic neurologic disorder characterized by episodes of seizure (of various types), which generally require lifelong management with medication 
(Atif et al. 2016). Children and adults are both affected by this disease. Approximately 1 in 26 people will develop epilepsy at some point in their lives (England et al. 2012). Sexual dysfunction associated with epilepsy is not yet completely understood (Harden 2008) and epilepsy is a complex disease causing several downstream pathological alterations which may need further exploration and treatment. One manifestation of the disease includes endocrine disorders in men and women which influences the reproductive system. Reproductive endocrine disorders in epileptic women include polycystic ovary syndrome (PCOS) (Bauer and Cooper-Mahkorn 2008; Bilo et al. 1988; Herzog et al. 2003a, b, 1984; Hopkinson et al. 1998; Gorkemli et al. 2008), hypothalamic amenorrhea (Bilo et al. 2001; Herzog et al. 1986b), hyperandrogenemia (HA) (Luef et al. 2002b; Löfgren et al. 2007), galactorrhea, hirsutism, menstrual abnormality and infertility (Bauer 2001; Bauer et al. 2002; Herzog et al. 2003b; Löfgren et al. 2006). Sexual dysfunction impacts between one and two thirds (30-66\%) of epileptic men (Blumer and Walker 1967; Hierons and Saunders 1966; Herzog et al. 1986a) and between 14 and 50\% of epileptic women (Demerdash et al. 1991; Jensen 1992). Evidence suggests that (Edwards et al. 1999; Baird et al. 2003; Quigg et al. 2002; Morrell et al. 2005) patients with partial epilepsy (PE) are more severely affected by reproductive endocrine and sexual dysfunction than idiopathic generalized epileptic (IGE) patients, predominantly of temporal lobe origin (Table 3).

The underlying mechanism of reproductive dysfunction has various hypotheses. One of the most accepted hypotheses suggests that the activity of gonadotropinreleasing hormone $(\mathrm{GnRH})$ pulse generator is disturbed due to the temporal lobe regions associated with epilepsy, which might be the origin of paroxysmal release, just before the hypothalamus (Verrotti et al. 2015). Amplification of the pulse frequency of $\mathrm{GnRH}$ and as a result the luteinizing hormone (LH) and follicle-stimulating hormone (FSH) ratio is related among PCOS patients (Rauchenzauner et al. 2014). The decrease in GnRH pulse frequency also lowers LH and estrogen (E2) levels, which an attribute is of HA. Moreover, several other aspects, such as, obesity, genetic disposition, laterality of epilepsy, type of AED prescribed, age and severity of seizures, might also be reasons for clinical expression of specific reproductive disorders i.e. HA, PCOS, ovulation, hirsutism (Verrotti et al. 2011).

\section{The relationship between sexual dysfunction and AEDs}

Seizure disorders are linked with sexual dysfunction as part of the pathophysiology, whilst all the available AEDs have not yet been definitively proven to have negative impacts on sexual function. As such, evaluation of AEDinduced sexual dysfunction is complicated and less than clear (Crenshaw and Goldberg 1996; Gitlin 2003). Comparative analyses of AEDs in patients with epilepsy, inducing sexual dysfunction are hard to find. The enzyme stimulating AEDs (phenytoin, topiramate, phenobarbital, oxcarbazepine and carbamazepine) raise hepatic synthesis of sex hormone binding globulin (SHBG) that lessens the accessibility of testosterone. Additionally, enhanced sex hormone metabolism and contraceptive hormones are not found with the use of AEDs that do not stimulate hepatic enzymes (e.g. lamotrigine, valproate, gabapentin, and vigabatrin) (Herzog et al. 2005; Morrell 2003). A consistent finding in the literature is that sexual dysfunction occurs with greater prevalence in patients taking phenytoin and carbamazepine than in patients taking valproate or lamotrigine (Herzog et al. 2005; Gutierrez et al. 2008). Women treated with valproate for bipolar disorder have also been reported to have severely decreased libido and anorgasmia, while there are case reports of gabapentinassociated anorgasmia in women who suffer from epilepsy (Harden 2005). A review of pregabalin efficacy and tolerability makes no mention of sexual dysfunction as an observed adverse effect (Tassone et al. 2007). Several studies in men and women have indicated that AEDs are related to sexual dysfunction (Table 4).

\section{Antiepileptic drugs, epilepsy and serum sex hormones}

Sex hormones levels contribute to sexual dysfunction as well as other reproductive disorders and these levels can be change as a result of the administration of AEDs (Table 5) (Morrell et al. 2005). The reproductive endocrine system may also be influenced by the pathophysiological effects of epilepsy as a disease in its own right (Scharfman et al. 2008). Endocrinological alterations due to epilepsy can be postulated in spite of the complicated interconnection among the limbic system and the hypothalamic-pituitary axis (HPA). Production toward HPA from the limbic cortex, containing nuclear configuration inside the amygdale, can alter key features in the discharge of sex hormones. Reproductive functions and discharge of sex hormones are affected by the influence of epilepsy in the medial temporal lobe region of the brain (Herzog et al. 1986b). Though the complexity it remains uncertain as to whether hormonal irregularity is because of epilepsy associated HPA dysfunction or whether it is due to the side effects of AEDs (Verrotti et al. 2011). The role of the HPA, the production of LH and FSH, GnRH, prolactin (PRL), and the end products of metabolism and their concentrations i.e. E2, T (testosterone), and DHEAS (dehydroepiandrosterone), are altered in epileptic women (Table 5) (Morrell 2003; Genton et al. 2001). 
Table 3 Studies of epilepsy type and sexual and reproductive dysfunction

\begin{tabular}{|c|c|c|c|c|c|}
\hline Dysfunction assessed & Epilepsy type & $\operatorname{Sex}(n)$ & Prevalence & Sexual dysfunction assessment & References \\
\hline \multicolumn{6}{|l|}{ Sexual } \\
\hline \multirow[t]{2}{*}{$\begin{array}{l}\text { i. Global anorgasmia } \\
\text { ii. Vaginismus } \\
\text { iii. Dyspareunia }\end{array}$} & $P E$ & F (99) & $\begin{array}{l}\text { i. } 17.9 \% \\
\text { ii. } 27.8 \% \\
\text { iii. } 38.5 \%\end{array}$ & Questionnaire & Morrell and Guldner (1996) \\
\hline & IGE & $F(17)$ & $\begin{array}{l}\text { i. } 31.3 \% \\
\text { ii. } 13.3 \% \\
\text { iii. } 18.8 \%\end{array}$ & & \\
\hline \multirow[t]{2}{*}{$\begin{array}{l}\text { i. Sexual arousability } \\
\text { ii. Sexual anxiety }\end{array}$} & $\mathrm{PE}$ & $F(99)$ & $\begin{array}{l}\text { i. } 72.2 \% \\
\text { ii. } 15.4 \%\end{array}$ & Questionnaire & Lambert (2001) \\
\hline & IGE & $F(17)$ & $\begin{array}{l}\text { i. } 84.2 \% \\
\text { ii. } 7.6 \%\end{array}$ & & \\
\hline \multirow[t]{2}{*}{ Erectile dysfunction } & GTCS & M (25) & $72 \%$ & Questionnaire & Nikoobakht et al. (2007) \\
\hline & PE & $M(16)$ & $32 \%$ & & \\
\hline \multirow[t]{2}{*}{ Erectile dysfunction } & PE & M (418) & $25.8 \%$ & Clinical interview & Keller et al. (2012) \\
\hline & IGE & M (166) & $29.5 \%$ & & \\
\hline \multicolumn{6}{|l|}{ Reproductive } \\
\hline \multirow[t]{2}{*}{$\begin{array}{l}\text { i. Menstrual disorders } \\
\text { ii. PCO } \\
\text { iii. HA } \\
\text { iv. PCOS }\end{array}$} & $\mathrm{PE}$ & $F(90)$ & $\begin{array}{l}\text { i. } 44 \% \\
\text { ii. } 46 \% \\
\text { iii. } 33 \% \\
\text { iv. } 44 \%\end{array}$ & Clinical examination, transvaginal ultrasonography & Löfgren et al. (2007) \\
\hline & IGE & $F(57)$ & $\begin{array}{l}\text { i. } 29 \% \\
\text { ii. } 28 \% \\
\text { iii. } 13 \% \\
\text { iv. } 19 \%\end{array}$ & & \\
\hline \multirow[t]{2}{*}{$\begin{array}{l}\text { i. Menstrual disorders } \\
\text { ii. Hirsutism } \\
\text { iii. PCO }\end{array}$} & IGE & $F(52)$ & $\begin{array}{l}\text { i. } 23 \% \\
\text { ii. } 5.8 \% \\
\text { iii. } 25 \%\end{array}$ & Clinical examination, transvaginal ultrasonography & Luef et al. (2002a) \\
\hline & PE & $F(40)$ & $\begin{array}{l}\text { i. } 42.5 \% \\
\text { ii. } 2.5 \% \\
\text { iii. } 37.5 \%\end{array}$ & & \\
\hline \multirow[t]{2}{*}{ PCO } & IGE & $F(36)$ & $21 \%$ & Suprapubic ovary ultrasound & Murialdo et al. (1997) \\
\hline & PE & $F(65)$ & $14.5 \%$ & & \\
\hline \multirow{2}{*}{$\begin{array}{l}\text { i. Hypomenorrhoea } \\
\text { ii. Amenorrhea } \\
\text { iii. Oligomenorrhoea } \\
\text { iv. Polymenorrhoea }\end{array}$} & IGE & $F(21)$ & \multirow{2}{*}{$\begin{array}{l}\text { Overall results } \\
\text { i. } 22 \% \\
\text { ii. } 16 \% \\
\text { iii. } 9 \% \\
\text { iv. } 2 \%\end{array}$} & \multirow[t]{2}{*}{ Clinical examination } & \multirow[t]{2}{*}{ Demerdash et al. (1991) } \\
\hline & PE & $F(106)$ & & & \\
\hline
\end{tabular}

PCO polycystic ovaries, HA hyperandrogenism, PCOS polycystic ovary syndrome, IGE idiopathic generalized epilepsy, $P E$ partial epilepsy, $F$ female

\section{Treatment of sexual dysfunction}

Appropriate treatment to be provided for epileptic patients with sexual dysfunction requires evaluation according to patient requirements, epileptic condition and comorbidities and the medicines available for managing epilepsy. Various approaches might be helpful for treatment of sexual dysfunction in epileptic patients including;

- Behavioral approaches to enhance sexual performance.

- Waiting for tolerance to develop.

- Dose reduction of current medicines.

- Drug administration delayed until after sex.
- Adjuvant treatment of the sexual dysfunction per se.

- Varying the diverse range of antiepileptic's available for individual patients.

Several adjuvant medicines i.e. buspirone, yohimbine, neostigmine, cyproheptadine, mianserin, amantadine and dexamphetamine, are used to cure AEDs related sexual dysfunction (Shapira 2003). ED in men can be treated by using indicative approaches in combination with previously described treatment approaches. This might include corporal initiation of the penis to stimulate spinal reflexes, and loss of blood can be prevented by inserting elastic constricting bands at the base, and negative pressure facilitating cavernous blood flow 
Table 4 Anti-epileptic drugs associated with sexual dysfunction

\begin{tabular}{|c|c|c|c|c|c|c|}
\hline Drug and dose (mg) & $\begin{array}{l}\text { Dysfunction } \\
\text { assessed }\end{array}$ & $\operatorname{Sex}(n)$ & Prevalence & Diagnosis & $\begin{array}{l}\text { Sexual dysfunction } \\
\text { assessment }\end{array}$ & References \\
\hline \multicolumn{7}{|l|}{ Sexual dysfunctions } \\
\hline Primidone (250) & $\begin{array}{l}\text { Decreased libido or } \\
\text { impotence }\end{array}$ & M (109) & $22 \%$ & GTCS & Questionnaire & Mattson et al. (1985) \\
\hline Carbamazepine (580) & \multirow[t]{3}{*}{ Sperm abnormality } & M (13) & $77 \%$ & \multirow[t]{3}{*}{ IGE, PE } & \multirow{3}{*}{$\begin{array}{l}\text { Semen analysis and } \\
\text { ultrasonography of } \\
\text { testicles }\end{array}$} & \multirow[t]{3}{*}{ Isojärvi et al. (2004) } \\
\hline Oxcarbazepine (1060) & & $M(17)$ & $59 \%$ & & & \\
\hline Valproate (1080) & & M (25) & $80 \%$ & & & \\
\hline Topiramate (100-200) & \multirow{3}{*}{$\begin{array}{l}\text { Erectile dysfunction } \\
\text { i. Erectile dysfunction } \\
\text { ii. Premature ejacula- } \\
\text { tion } \\
\text { iii. Orgasm dysfunction } \\
\text { iv. Diminished sexual } \\
\text { desire }\end{array}$} & $M(40)$ & $5 \%$ & $P E$ & Clinical interview & Holtkamp et al. (2005) \\
\hline Valproate (400-1250) & & M (8) & $\begin{array}{l}\text { i. } 50 \% \\
\text { ii. } 50 \% \\
\text { iii. } 0.0 \% \\
\text { iv. } 62.5 \%\end{array}$ & \multirow[t]{2}{*}{ GTCS } & \multirow[t]{2}{*}{$\begin{array}{l}\text { Sexual function ques- } \\
\text { tionnaire }\end{array}$} & \multirow[t]{2}{*}{ Hamed et al. (2006) } \\
\hline $\begin{array}{l}\text { Carbamazepine } \\
(400-1000)\end{array}$ & & $M(17)$ & $\begin{array}{l}\text { i. } 47.1 \% \\
\text { ii. } 35.3 \% \\
\text { iii. } 5.9 \% \\
\text { iv. } 52.9 \%\end{array}$ & & & \\
\hline Pregabalin (150-600) & Erectile dysfunction & M (363) & $3.0 \%$ & $P E$ & Questionnaire & Hitiris et al. (2006) \\
\hline Lamotrigine (50-200) & Lack of sexual interest & $M(75), F(66)$ & $11 \%$ & Complex PE, IGE & $\begin{array}{l}\text { Changes in sexual } \\
\text { functioning ques- } \\
\text { tionnaire (CSFQ) }\end{array}$ & Gil-Nagel et al. (2006) \\
\hline Phenytoin (100) & Retrograde ejaculation & $M(1)$ & Case report & $P E$ & Clinical examination & Elia et al. (2010) \\
\hline Zonisamide (200) & Erectile dysfunction & $M(1)$ & Case report & PE & Clinical interview & Maschio et al. (2011) \\
\hline Gabapentin (900) & Anorgasmia & $F(1)$ & Case report & GTCS & Clinical interview & Perloff et al. (2011) \\
\hline $\begin{array}{l}\text { Leviteracetam } \\
(2000-3000)\end{array}$ & $\begin{array}{l}\text { i. Decreased libido } \\
\text { ii. Erectile dysfunction } \\
\text { iii. Anhedonia }\end{array}$ & $M(2)$ & Case reports & $\begin{array}{l}\text { GTCS, Myoclonic } \\
\text { seizures }\end{array}$ & Clinical interview & Calabrò et al. (2012) \\
\hline Pregabalin (300) & Anorgasmia & M (4) & Case reports & $P E$ & Clinical interview & Calabrò et al. (2013) \\
\hline $\begin{array}{l}\text { Leviteracetam } \\
\quad(500-1000)\end{array}$ & Sperm abnormality & $M(10)$ & $69.2 \%$ & GTCS, complex PE & $\begin{array}{l}\text { Computer-aided } \\
\text { sperm analysis }\end{array}$ & Xiaotian et al. (2013) \\
\hline Valproate (500-1000) & & M (15) & $18.8 \%$ & & & \\
\hline Lacosamide (400) & $\begin{array}{l}\text { i. Loss of libido } \\
\text { ii. Erectile dysfunction }\end{array}$ & $M(1)$ & Case report & $\begin{array}{l}\text { Simple and complex } \\
\text { seizures }\end{array}$ & Clinical examination & Calabro (2016) \\
\hline
\end{tabular}

GTCS generalized tonic-clonic seizure, PE partial epilepsy, IGE idiopathic generalized epilepsy

generated by using vacuum devices (Guldner and Morrell 1996). Additionally, methods such as the intercavernosal injection of vasodilators, i.e. papaverine or a grouping of papaverine, phentolamine, and prostaglandin E1, or yohimbine can be used to treat ED (Smaldone et al. 2004; Rokkas 2015). Other pharmaco-therapies for combatting ED to enhance the quality and frequency of erection include; topical nitroglycerine, topical minoxidil, and sildenafil (Rokkas 2015). The authors are not aware of any research that has been conducted on the use of sildenafil for ED in epileptic patients. Phosphodiesterase type- 5 inhibitor drugs are now the first-line treatment for ED (Shamloul and Ghanem 2013; Bruzziches et al. 2013; Lee et al. 2015). Selective serotonin reuptake inhibitors (for example; escitalopram, paroxetine, fluoxetine, sertraline, etc.) and topical anesthetic creams are available but are not approved for the ED indication. However, they still serve as effective off-label treatments for premature ejaculation (Stimmel and Gutierrez 2006). Testosterone and aromatase inhibitors have been used in the investigational setting to treat sexual dysfunction in men taking AEDs (Hamed et al. 2013). Patient education and follow-up appointments are essential to ensure the optimal outcomes of pharmacologic treatment for sexual dysfunction in the epileptic patient. There are no approved pharmacologic treatments for female hypoactive sexual desire disorder or female orgasmic disorder. However, female sexual arousal disorder is treated with either estrogen replacement therapy or vaginal lubricants (Gutierrez et al. 2008).

\section{Conclusions and recommendations}

Sexual dysfunction in the epileptic patient is complex as it is often difficult to determine whether the dysfunction is disease or treatment related. There is a scarcity of data on the occurrence of sexual dysfunction 


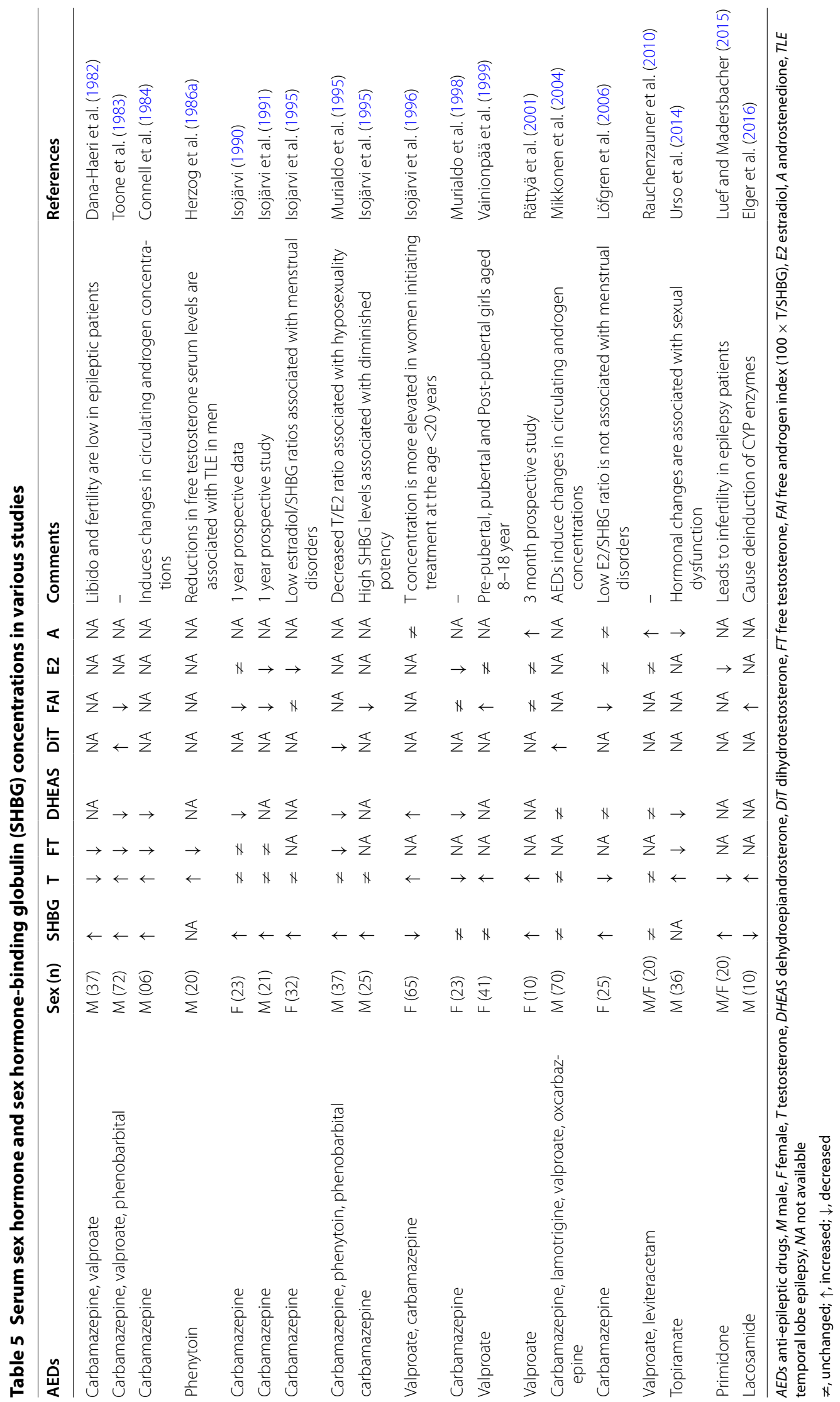


among the population as a whole and amongst those taking AEDs which can induce sexual dysfunction. This is a broad review looking at sexual dysfunction but the primary aim is to better understand the literature surrounding sexual dysfunction in the epileptic patient where both the pathophysiology and the treatment can cause a degree of sexual dysfunction. This review concluded that the most common sexual dysfunction in males is ED and early ejaculation while females complain of lack of interest in sex and failing to reach orgasm.

Epilepsy is associated with sexual dysfunction while it is not yet known whether all AEDs have a negative impact on sexual function. Unraveling the causations of AED-induced sexual dysfunction in the epileptic patient is complicated. Sex hormone levels can be changed due to AEDs which are the cause of sexual dysfunction and reproductive disorders. Systematic studies are needed to explore the risks and mechanisms of such treatment related side effects on sexual function; particularly in epileptics. This review lead to the following recommendations for physicians in improving the management of sexual dysfunction for their patients: (1) improved electronic medical record template to include appropriate questions related to sexual dysfunction in appropriate populations such as epileptics; (2) revision of undergraduate and residency curricula to include a broader appreciation of the impact of illness processes, comorbidities, and associated pharmacotherapies upon sexual functioning; and (3) required continuing medical education on sexual dysfunction.

\begin{abstract}
Abbreviations
AEDs: antiepileptic drugs; ED: erectile dysfunction; ICD-10: International Classification of Mental and Behavioral Disorders, 10th edition; DSM-IV: Diagnostic and Statistical Manual of Mental Disorders, fourth edition; DHEAS: dehydroepiandrosterone; DiT: dihydrotestosterone; FT: free testosterone; FAl: free androgen index; E2: estradiol; A: androstenedione; TLE: temporal lobe epilepsy; PE: partial epilepsy; IGE: idiopathic generalized epilepsy.

\section{Authors' contributions}

MAT, MRS and SS contributed in the concept and design of this review article. MRS did the literature search. MAT and SS critically revised the paper for important intellectual content. All authors read and approved the final manuscript.
\end{abstract}

\section{Author details}

1 Department of Pharmacy, The Islamia University of Bahawalpur, Bahawalpur, Punjab, Pakistan. ${ }^{2}$ School of Management, Massey University, Auckland, New Zealand.

\section{Acknowledgements}

None.

\section{Competing interests}

The authors declare that they have no competing interests.

Received: 18 March 2016 Accepted: 26 November 2016

Published online: 02 December 2016
References

American Psychiatric Association (2000) Diagnostic and statistical manual of mental disorders, text revision (DSM-IV-TR). American Psychiatric Association, Washington, DC

Atif M, Azeem M, Sarwar MR (2016) Potential problems and recommendations regarding substitution of generic antiepileptic drugs: a systematic review of literature. SpringerPlus 5(1):1

Baird AD, Wilson SJ, Bladin PF, Saling MM, Reutens DC (2003) Sexual outcome after epilepsy surgery. Epilepsy Behav 4(3):268-278

Baldwin DS (2001) Depression and sexual dysfunction. Br Med Bull 57(1):81-99

Baldwin D, Birtwistle J (1997) Schizophrenia, antipsychotic drugs and sexual function. Primary Care Psychiatry 3:115-124

Baldwin DS, Thomas SC, Birtwistle J (1997) Effects of antidepressant drugs on sexual function. Int J Psychiatry Clin Pract 1(1):47-58

Bancroft J (2009) Human sexuality and its problems. Elsevier Health Sciences, Amsterdam

Bauer J (2001) Interactions between hormones and epilepsy in female patients. Epilepsia 42(s3):20-22

Bauer J, Cooper-Mahkorn D (2008) Reproductive dysfunction in women with epilepsy: menstrual cycle abnormalities, fertility, and polycystic ovary syndrome. Int Rev Neurobiol 83:135-155

Bauer J, Isojärvi Jl, Herzog A, Reuber M, Polson D, Taubøll E, Genton P, Van Der Ven H, Roesing B, Luef G (2002) Reproductive dysfunction in women with epilepsy: recommendations for evaluation and management. J Neurol Neurosurg Psychiatry 73(2):121-125

Bhavsar V, Bhugra D (2013) Cultural factors and sexual dysfunction in clinical practice. Adv Psychiatr Treat 19(2):144-152

Bhugra D, de Silva P (2007) Sexual dysfunction across cultures. In: Textbook of cultural psychiatry. pp 364-378

Bilo L, Meo R, Nappi C, Annunziato L, Striano S, Colao AM, Merola B, Buscaino GA (1988) Reproductive endocrine disorders in women with primary generalized epilepsy. Epilepsia 29(5):612-619

Bilo L, Meo R, Valentino R, Di Carlo C, Striano S, Nappi C (2001) Characterization of reproductive endocrine disorders in women with epilepsy. J Clin Endocrinol Metab 86(7):2950-2956

Blumer D, Walker AE (1967) Sexual behavior in temporal lobe epilepsy: a study of the effects of temporal lobectomy on sexual behavior. Arch Neurol 16(1):37-43

Bruzziches R, Francomano D, Gareri P, Lenzi A, Aversa A (2013) An update on pharmacological treatment of erectile dysfunction with phosphodiesterase type 5 inhibitors. Expert Opin Pharmacother 14(10):1333-1344

Burri A, Spector T (2011) Recent and lifelong sexual dysfunction in a female UK population sample: prevalence and risk factors. J Sex Med 8(9):2420-2430

Calabro R (2016) Sexual dysfunction: case report. Reactions 1583:669

Calabrò RS, Italiano D, Militi D, Bramanti P (2012) Levetiracetam-associated loss of libido and anhedonia. Epilepsy Behav 24(2):283-284

Calabrò RS, De Luca R, Pollicino P, Bramanti P (2013) Anorgasmia during pregabalin add-on therapy for partial seizures. Epileptic Disord 15(3):358-361

Christensen BS, Grønbæk M, Osler M, Pedersen BV, Graugaard C, Frisch M (2011) Sexual dysfunctions and difficulties in Denmark: prevalence and associated sociodemographic factors. Arch Sex Behav 40(1):121-132

Connell J, Rapeport W, Beastall G, Brodie M (1984) Changes in circulating androgens during short term carbamazepine therapy. Br J Clin Pharmacol 17(3):347-351

Crenshaw TL, Goldberg JP (1996) Sexual pharmacology: Drugs that affect sexual functioning. WW Norton \& Co, New York

Dalal A, Zhou L (2008) Gabapentin and sexual dysfunction: report of two cases. Neurologist 14(1):50-51

Dana-Haeri J, Oxley J, Richens A (1982) Reduction of free testosterone by antiepileptic drugs. BMJ 284(6309):85-86

Demerdash A, Shaalan M, Midani A, Kamel F, Bahri M (1991) Sexual behavior of a sample of females with epilepsy. Epilepsia 32(1):82-85

Edwards HE, Burnham WM, Ng MM, Asa S, MacLusky NJ (1999) Limbic seizures alter reproductive function in the female rat. Epilepsia 40(10):1370-1377

Elger CE, Rademacher M, Brandt C, Elmoufti S, Dedeken P, Eckhardt K, Tennigkeit F, De Backer M (2016) Changes in hormone and lipid levels in male patients with focal seizures when switched from carbamazepine to lacosamide as adjunctive treatment to levetiracetam: a small phase IIIb, prospective, multicenter, open-label trial. Epilepsy Behav 62:1-5 
Elia J, Imbrogno N, Delfino M, Mazzilli F (2010) Retrograde ejaculation and abnormal hormonal profile in a subject under treatment with valproate and phenytoin. Arch Ital Urol Androl 82(4):193-194

England MJ, Liverman CT, Schultz AM, Strawbridge LM (2012) Epilepsy across the spectrum: promoting health and understanding: a summary of the Institute of Medicine report. Epilepsy Behav 25(2):266-276

Ernst C, Földényi M, Angst J (1993) The Zurich Study: XXI. Sexual dysfunctions and disturbances in young adults. Eur Arch Psychiatry Clin Neurosci 243(3-4):179-188

Fogari R, Zoppi A, Corradi L, Mugellini A, Poletti L, Lusardi P (1998) Sexual function in hypertensive males treated with lisinopril or atenolol: a cross-over study. Am J Hypertens 11(10):1244-1247

Garde K, Lunde I (1980) Social background and social status; influence on female sexual behaviour. A random sample study of 40-year-old Danish women. Maturitas 2(3):241-246

Genton P, Bauer J, Duncan S, Taylor AE, Balen AH, Eberle A, Pedersen B, SalasPuig X, Sauer MV (2001) On the association between valproate and polycystic ovary syndrome. Epilepsia 42(3):295-304

Gil-Nagel A, Lopez-Munoz F, Serratosa J, Moncada I, Garcia-Garcia P, Alamo C (2006) Effect of lamotrigine on sexual function in patients with epilepsy. Seizure 15(3):142-149

Gitlin M (2003) Sexual dysfunction with psychotropic drugs. Expert Opin Pharmacother 4(12):2259-2269

Goldstein BJ, Goodnick PJ (1998) Selective serotonin reuptake inhibitors in the treatment of affective disorders-III. Tolerability, safety and pharmacoeconomics. J Psychopharmacol 12(4 suppl):S55-S87

Gorkemli H, Genc BO, Dogan EA, Genc E, Ozdemir S (2008) Long-term effects of valproic acid on reproductive endocrine functions in Turkish women with epilepsy. Gynecol Obstet Invest 67(4):223-227

Grant AC, Oh H (2002) Gabapentin-induced anorgasmia in women. Am J Psychiatry 159(7):1247

Guldner GT, Morrell MJ (1996) Nocturnal penile tumescence and rigidity evaluation in men with epilepsy. Epilepsia 37(12):1211-1214

Gutierrez MA, Mushtaq R, Stimmel G (2008) Sexual dysfunction in women with epilepsy: role of antiepileptic drugs and psychotropic medications. Int Rev Neurobiol 83:157-167

Hamed S, Mohamed K, El-Taher A, Hamed E, Omar H (2006) The sexual and reproductive health in men with generalized epilepsy: a multidisciplinary evaluation. Int J Impot Res 18(3):287-295

Hamed SA, Ahmad HK, Youssef AH, Metwaly NA-H, Hassan MM, Mohamad HO (2013) Erectile function in men with epilepsy: relationship to psychosocial, hormonal, epilepsy and antiepileptic drugsrelated variables. J Neurol Neurosci 4(2):5

Hamed SA, Hermann BP, Moussa EM, Youssef AH, Rageh TA, Elserogy YE, NasrEldin E (2015) Evaluation of penile vascular status in men with epilepsy with erectile dysfunction. Seizure 25:40-48

Harden CL (2005) Sexuality in women with epilepsy. Epilepsy Behav 7:2-6

Harden CL (2008) Sexual dysfunction in women with epilepsy. Seizure 17(2):131-135

Hendrickx L, Gijs L, Enzlin P (2016) Sexual difficulties and associated sexual distress in Flanders (Belgium): a representative population-based survey study. The journal of sexual medicine 13(4):650-668

Herzog AG, Seibel MM, Schomer D, Vaitukaitis J, Geschwind N (1984) Temporal lobe epilepsy: an extrahypothalamic pathogenesis for polycystic ovarian syndrome? Neurology 34(10):1389

Herzog AG, Seibel MM, Schomer DL, Vaitukaitis JL, Geschwind N (1986a) Reproductive endocrine disorders in men with partial seizures of temporal lobe origin. Arch Neurol 43(4):347-350

Herzog AG, Seibel MM, Schomer DL, Vaitukaitis JL, Geschwind N (1986b) Reproductive endocrine disorders in women with partial seizures of temporal lobe origin. Arch Neurol 43(4):341-346

Herzog AG, Coleman AE, Jacobs AR, Klein P, Friedman MN, Drislane FW, Ransil BJ, Schomer DL (2003a) Interictal EEG discharges, reproductive hormones, and menstrual disorders in epilepsy. Ann Neurol 54(5):625-637

Herzog AG, Coleman AE, Jacobs AR, Klein P, Friedman MN, Drislane FW, Schomer DL (2003b) Relationship of sexual dysfunction to epilepsy laterality and reproductive hormone levels in women. Epilepsy Behav 4(4):407-413

Herzog A, Drislane F, Schomer D, Pennell P, Bromfield E, Dworetzky B, Farina E, Frye C (2005) Differential effects of antiepileptic drugs on sexual function and hormones in men with epilepsy. Neurology 65(7):1016-1020
Hierons R, Saunders M (1966) Impotence in patients with temporal-lobe lesions. Lancet 288(7467):761-764

Hitiris N, Barrett JA, Brodie MJ (2006) Erectile dysfunction associated with pregabalin add-on treatment in patients with partial seizures: five case reports. Epilepsy Behav 8(2):418-421

Holtkamp M, Weissinger F, Meierkord H (2005) Erectile dysfunction with topiramate. Epilepsia 46(1):166-167

Hopkinson ZE, Sattar N, Fleming R, Greer IA (1998) Fortnightly review: polycystic ovarian syndrome: the metabolic syndrome comes to gynaecology. Br Med J 317(7154):329

Isojärvi JI (1990) Serum steroid hormones and pituitary function in female epileptic patients during carbamazepine therapy. Epilepsia 31(4):438-445

Isojarvi Jl, Repo M, Pakarinen AJ, Lukkarinen O, Myllylä WV (1995) Carbamazepine, phenytoin, sex hormones, and sexual function in men with epilepsy. Epilepsia 36(4):366-370

Isojärvi Jl, Pakarinen AJ, Myllylä WV (1991) A prospective study of serum sex hormones during carbamazepine therapy. Epilepsy Res 9(2):139-144

Isojärvi Jl, Laatikainen TJ, Pakarinen AJ, Juntunen KT, Myllylä W (1995) Menstrual disorders in women with epilepsy receiving carbamazepine. Epilepsia 36(7):676-681

Isojärvi Jl, Laatikainen TJ, Knip M, Pakarinen AJ, Juntunen KT, Myllyla WV (1996) Obesity and endocrine disorders in women taking valproate for epilepsy. Ann Neurol 39(5):579-584

Isojärvi J, Löfgren E, Juntunen K, Pakarinen A, Päivänsalo M, Rautakorpi I, Tuomivaara L (2004) Effect of epilepsy and antiepileptic drugs on male reproductive health. Neurology 62(2):247-253

Jensen SB (1992) Sexuality and chronic illness: a biopsychosocial approach. Semin Neurol 12(2):135-140

Kaufman K, Struck P (2011a) Dose-dependent gabapentin-induced sexual dysfunction. Epilepsia 52:228

Kaufman KR, Struck PJ (2011 b) Gabapentin-induced sexual dysfunction. Epilepsy Behav 21(3):324-326

Kaufman KR, Wong S, Sivaraaman K, Anim C, Delatte D (2015) Epilepsy and AED-induced decreased libido-the unasked psychosocial comorbidity. Epilepsy Behav 52:236-238

Keller J, Chen YK, Lin HC (2012) Association between epilepsy and erectile dysfunction: evidence from a population-based study. J Sex Med 9(9):2248-2255

Kirmani BF, Robinson DM, Kikam A, Fonkem E, Cruz D (2014) Selection of antiepileptic drugs in older people. Curr Treat Options eurol 16(6):1-16

Lambert MV (2001) Seizures, hormones and sexuality. Seizure 10(5):319-340

Laumann EO, Paik A, Rosen RC (1999) Sexual dysfunction in the United States: prevalence and predictors. JAMA 281(6):537-544

Lee D, Nazroo J, Pendleton N (2015) Erectile dysfunction and phosphodiesterase type 5 inhibitor use: associations with sexual activities, function and satisfaction in a population sample of older men. Int J Impot Res 27(4):146-151

Lindau ST, Schumm LP, Laumann EO, Levinson W, O'Muircheartaigh CA, Waite $\llcorner J$ (2007) A study of sexuality and health among older adults in the United States. N Engl J Med 357(8):762-774

Löfgren E, Tapanainen JS, Koivunen R, Pakarinen A, Isojärvi JI (2006) Effects of carbamazepine and oxcarbazepine on the reproductive endocrine function in women with epilepsy. Epilepsia 47(9):1441-1446

Löfgren E, Mikkonen K, Tolonen U, Pakarinen A, Koivunen R, Myllyla W, Tapanainen JS, Isojärvi JI (2007) Reproductive endocrine function in women with epilepsy: the role of epilepsy type and medication. Epilepsy Behav 10(1):77-83

Lombardi G, Musco S, Kessler TM, Li Marzi V, Lanciotti M, Del Popolo G (2015) Management of sexual dysfunction due to central nervous system disorders: a systematic review. BJU Int 115:47-56

Luef G, Madersbacher H (2015) Sexual dysfunction in patients with epilepsy. Handb Clin Neurol 130:383-394

Luef G, Abraham I, Haslinger M, Trinka E, Seppi K, Unterberger I, Alge A, Windisch J, Lechleitner M, Bauer G (2002a) Polycystic ovaries, obesity and insulin resistance in women with epilepsy. J Neurol 249(7):835-841

Luef G, Abraham I, Trinka E, Alge A, Windisch J, Daxenbichler G, Unterberger I, Seppi K, Lechleitner M, Krämer G (2002b) Hyperandrogenism, postprandial hyperinsulinism and the risk of PCOS in a cross sectional study of women with epilepsy treated with valproate. Epilepsy Res 48(1):91-102 
Maschio M, Saveriano F, Dinapoli L, Jandolo B (2011) Reversible erectile dysfunction in a patient with brain tumor-related epilepsy in therapy with zonisamide in add-on. J Sex Med 8(12):3515-3517

Mattson RH, Cramer JA, Collins JF, Smith DB, Delgado-Escueta AV, Browne TR, Williamson PD, Treiman DM, McNamara JO, McCutchen CB (1985) Comparison of carbamazepine, phenobarbital, phenytoin, and primidone in partial and secondarily generalized tonic-clonic seizures. N Engl J Med 313(3):145-151

McCabe MP, Sharlip ID, Lewis R, Atalla E, Balon R, Fisher AD, Laumann E, Lee SW, Segraves RT (2016) Incidence and prevalence of sexual dysfunction in women and men: a consensus statement from the Fourth International Consultation on Sexual Medicine 2015. J Sex Med 13(2):144-152

Meryn S (2015) Erectile dysfunction in the elderly. Springer, Berlin, pp 159-166

Mialon A, Berchtold A, Michaud P-A, Gmel G, Suris J-C (2012) Sexual dysfunctions among young men: prevalence and associated factors. J Adolesc Health 51(1):25-31

Mikkonen K, Tapanainen P, Pakarinen AJ, Päivänsalo M, Isojärvi Jl, Vainionpää LK (2004) Serum androgen levels and testicular structure during pubertal maturation in male subjects with epilepsy. Epilepsia 45(7):769-776

Montejo-Gonzalez AL, Llorca G, Izquierdo J, Ledesma A, Bousono M, Calcedo A, Carrasco J, Ciudad J, Daniel E, De La Gandara J (1997) Fluoxetine, paroxetine, sertraline, and fluvoxamine in a prospective, multicenter, and descriptive clinical study of 344 patients. J Sex Marital Ther 23(3):176-194

Morrell MJ (2003) Reproductive and metabolic disorders in women with epilepsy. Epilepsia 44(s4):11-20

Morrell MJ, Guldner GT (1996) Self-reported sexual function and sexual arousability in women with epilepsy. Epilepsia 37(12):1204-1210

Morrell MJ, Flynn KL, Doñe S, Flaster E, Kalayjian L, Pack AM (2005) Sexual dysfunction, sex steroid hormone abnormalities, and depression in women with epilepsy treated with antiepileptic drugs. Epilepsy Behav 6(3):360-365

Murialdo G, Galimberti CA, Fonzi S, Manni R, Costelli P, Parodi C, Solinas GP, Amoretti G, Tartara A (1995) Sex hormones and pituitary function in male epileptic patients with altered or normal sexuality. Epilepsia 36(4):360-365

Murialdo G, Galimberti C, Magri F, Sampaolo P, Copello F, Gianelli M, Gazzerro E, Rollero A, Deagatone C, Manni R (1997) Menstrual cycle and ovary alterations in women with epilepsy on antiepileptic therapy. J Endocrinol Invest 20(9):519-526

Murialdo G, Galimberti C, Gianelli M, Rollero A, Polleri A, Copello F, Magri F, Ferrari E, Sampaolo P, Manni R (1998) Effects of valproate, phenobarbital, and carbamazepine on sex steroid setup in women with epilepsy. Clin Neuropharmacol 21(1):52-58

Nathan SG (1986) The epidemiology of the DSM-III psychosexual dysfunctions. J Sex Marital Ther 12(4):267-281

Nikoobakht M, Motamedi M, Orandi A, Meysamie A, Emamzadeh A (2007) Sexual dysfunction in epileptic men. Urol J 4(2):111-117

Osborn M, Hawton K, Gath D (1988) Sexual dysfunction among middle aged women in the community. BMJ 296(6627):959-962

Perloff MD, Thaler DE, Otis JA (2011) Anorgasmia with gabapentin may be common in older patients. Am J Geriatr Pharmacother 9(3):199-203

Quigg M, Kiely JM, Shneker B, Veldhuis JD, Bertram EH (2002) Interictal and postictal alterations of pulsatile secretions of luteinizing hormone in temporal lobe epilepsy in men. Ann Neurol 51(5):559-566

Rättyä J, Pakarinen AJ, Knip M, Repo-Outakoski M, Myllylä VV, Isojärvi JI (2001) Early hormonal changes during valproate or carbamazepine treatment: a 3-month study. Neurology 57(3):440-444
Rauchenzauner M, Bitsche G, Svalheim S, Tauboll E, Haberlandt E, Wildt L, Rostasy K, Luef G (2010) Effects of levetiracetam and valproic acid monotherapy on sex-steroid hormones in prepubertal children-results from a pilot study. Epilepsy Res 88(2):264-268

Rauchenzauner M, Roscia S, Prieschl M, Wildt L, Haberlandt E, Baumann M, Rostasy K, Agostinelli S, Pizzolorusso A, Luef G (2014) Reproductive endocrine health in pubertal females with epilepsy on antiepileptic drugs: time to screen? Neuropediatrics 45(04):226-233

Rokkas K (2015) Management of erectile dysfunction beyond PDE-5 inhibitors. Springer, Berlin, pp 195-203

Safarinejad M (2006) Female sexual dysfunction in a population-based study in Iran: prevalence and associated risk factors. Int J Impot Res 18(4):382-395

Scharfman HE, Kim M, Hintz TM, MacLusky NJ (2008) Seizures and reproductive function: insights from female rats with epilepsy. Ann Neurol 64(6):687-697

Shamloul R, Ghanem H (2013) Erectile dysfunction. Lancet 381 (9861):153-165

Shapira N (2003) Methods of treating medication-, substance-, disease-, and other medical condition-related sexual dysfunction. Google Patents

Sivaraaman K, Mintzer S (2011) Hormonal consequences of epilepsy and its treatment in men. Curr Opin Endocrinol Diabetes Obes 18(3):204-209

Smaldone M, Sukkarieh T, Reda A, Khan A (2004) Epilepsy and erectile dysfunction: a review. Seizure 13(7):453-459

Stimmel GL, Gutierrez MA (2006) Pharmacologic treatment strategies for sexual dysfunction in patients with epilepsy and depression. CNS Spectr 11(S9):31-37

Sungur MZ, Bez Y (2016) cultural factors in the treatment of sexual dysfunction in Muslim clients. Curr Sex Health Rep 8(2):57-63

Svalheim S, Sveberg L, Mochol M, Taubøll E (2015) Interactions between antiepileptic drugs and hormones. Seizure 28:12-17

Tassone DM, Boyce E, Guyer J, Nuzum D (2007) Pregabalin: a novel $\gamma$-aminobutyric acid analogue in the treatment of neuropathic pain partial-onset seizures, and anxiety disorders. Clin Ther 29(1):26-48

Toone B, Wheeler M, Nanjee M, Fenwick P, Grant R (1983) Sex hormones, sexual activity and plasma anticonvulsant levels in male epileptics. J Neurol Neurosurg Psychiatry 46(9):824-826

Urso L, Zummo L, Gammino M, Fierro B, Pavone C, Daniele O (2014) Antiepileptic drugs, sexual functions and serum hormonal profile in males with epilepsy. Med Surg Urol 3:130. doi:10.4172/2168-9857.1000130

Vainionpää LK, Rättyä J, Knip M, Tapanainen JS, Pakarinen AJ, Lanning P, Tekay A, Myllylä W, Isojärvi Jl (1999) Valproate-induced hyperandrogenism during pubertal maturation in girls with epilepsy. Ann Neurol 45(4):444-450

Verrotti A, D’Egidio C, Mohn A, Coppola G, Parisi P, Chiarelli F (2011) Antiepileptic drugs, sex hormones, and PCOS. Epilepsia 52(2):199-211

Verrotti A, Prezioso G, D'Egidio C, Belcastro V (2015) Reproductive hormones in epilepsy therapy: from old promises to new hopes. In: Epilepsy towards the next decade. Springer, Berlin, pp 201-211

World Health Organization (1992) The ICD-10 classification of mental and behavioural disorders: clinical descriptions and diagnostic guidelines. World Health Organization, Geneva

Xiaotian X, Hengzhong Z, Yao X, Zhipan Z, Daoliang X, Yumei W (2013) Effects of antiepileptic drugs on reproductive endocrine function, sexual function and sperm parameters in Chinese Han men with epilepsy. J Clin Neurosci 20(11):1492-1497 